\title{
Asam L Askorbat Meningkatkan Viabilitas HUVEC dalam Kultur P. falciparum yang Diinkubasi dengan Artemisinin Bergantung Konsentrasi
}

\author{
Susy Tjahjani, ${ }^{1}$ Tri Hanggono Achmad, ${ }^{2}$ Din Syafruddin ${ }^{3}$ \\ ${ }^{1}$ Fakultas Kedokteran Universitas Kristen Maranatha, \\ ${ }^{2}$ Fakultas Kedokteran Universitas Padjadjaran, Bandung, ${ }^{3}$ Eijkman Institute for Molecular Biology
}

\begin{abstract}
Abstrak
Artemisinin, antimalaria yang sangat ampuh terhadap parasit multiresisten, bekerja melalui produksi radikal bebas. Oleh karena terjadinya alur permeasi baru pada membran eritrosit yang terparasitisasi, asam L askorbat, suatu antioksidan hidrofilik, diharapkan tidak menembus membran tersebut sehingga tidak mempengaruhi daya antimalaria artemisinin melainkan hanya mempengaruhi sel inang di luar eritrosit yang terparasitisasi. Penelitian ini bertujuan untuk mempelajari pengaruh asam L askorbat pada viabilitas human umbilical vein endothelial cell (HUVEC) sebagai sel inang, kadar glutation sulfil hidril (GSH), dan kadar malondialdehyde (MDA) dalam kultur Plasmodium falciparum yang diinkubasi dengan artemisinin $\mathrm{IC}_{50}$ dan asam $\mathrm{L}$ askorbat. Penelitian ini dilakukan di Eijkman Insitute for Molecular Biology, Jakarta dari Januari 2007 sampai Januari 2008. Kultur Plasmodium falciparum strain 3D7 diinkubasi dengan artemisinin $\mathrm{IC}_{50}$ dan berbagai konsentrasi asam L askorbat selama 24 jam dalam candle jar dan inkubator $37^{\circ} \mathrm{C}$. Kadar GSH dan MDA pada supernatan diukur dengan spektrofotometri. Viabilitas HUVEC diukur dalam kokultur HUVEC- $P$. faciparum yang diinkubasi dengan artemisinin $\mathrm{IC}_{50}$ dan berbagai konsentrasi asam L askorbat. Data dianalisis dengan analysis of variance (ANOVA) dan Tukey honestly significant difference (HSD)/Scheffe. Eksperimen menunjukkan bahwa konsentrasi asam L askorbat $20 \mu \mathrm{M}$ dan $100 \mu \mathrm{M}$ dapat meningkatkan viabilitas HUVEC. Disimpulkan bahwa asam L askorbat meningkatkan viabilitas HUVEC dalam kultur $P$. falciparum yang diikubasi dengan artemisinin bergantung konsentrasi.
\end{abstract}

[MKB. 2011;43(2):66-71].

Kata kunci: Artemisinin, asam L askorbat, P. falciparum, viabilitas human umbilical vein endothelial cell

\section{Ascorbic Acid Concentration Dependently Increases HUVEC Viability in P. falciparum Culture Incubated with Artemisinin}

\begin{abstract}
Artemisinin via overproduction of free radical acts as a potent drug against multi-drug resistant Plasmodium. Because of new permeation pathway evidence at parasitized red blood cell membrane, L ascorbic acid as hydrophilic antioxidant hopefully can't penetrate the membrane so that it won't interfere the artemisinin antimalarial effect rather it protects the host cell out of parasitized erythrocytes. The aim of this study was to determine its effect against human umbilical vein endothelial cell (HUVEC) viability, glutathione sulfa-hydryl (GSH), and malondialdehyde (MDA) concentration in Plasmodium falciparum culture treated with artemisinin. This experiment was conducted at Eijkman Insitute for Molecular Biology, Jakarta from January 2007 to January 2008. Plasmodium falciparum 3D7 strain culture was incubated with $\mathrm{IC}_{50}$ of artemisinin and a wide concentration range of $\mathrm{L}$ ascorbic acid for 24 hours in a candle jar at $37^{\circ} \mathrm{C}$ incubator. GSH and MDA concentration were measured from the supernatant using spectrophotometer. HUVEC viability was measured in P. falciparum-HUVEC co-cultivation incubated with artemisinin $\mathrm{IC}_{50}$ and $\mathrm{L}$ ascorbic acid. The result was examined and analyzed using analysis of variance (ANOVA) and Tukey honestly significant difference (HSD)/Scheffe. It showed that $20 \mu \mathrm{M}$ and $100 \mu \mathrm{M} \mathrm{L}$ ascorbic acid raised the HUVEC viability. It was concluded that L ascorbic acid concentration dependently increases HUVEC viability in P. falciparum culture incubated with artemisinin. [MKB. 2011;43(2):66-71].
\end{abstract}

Key words: Artemisinin, human umbilical vein endothelial cell viability, L ascorbic acid, P. falciparum

Korespondensi: Dr. Susy Tjahjani, dr., M.Kes, Fakultas Kedokteran Universitas Kristen Maranatha, jalan Suria Sumantri 65 Bandung 40164, telepon (022) 2012186, mobile 08122004510,e-mail: susy_tjahjani@yahoo.com 


\section{Pendahuluan}

Setengah abad yang lalu malaria pada manusia berhasil dieliminasi atau ditekan dengan efektif di banyak bagian di dunia, terutama daerah subtropik. Adanya resistensi parasit plasmodium terhadap obat malaria, menyebabkan penyakit ini kini muncul lagi sebagai penyakit dengan morbiditas dan mortalitas yang tinggi di daerah yang tadinya sudah bebas malaria.

Artemisinin yang sangat berkhasiat terhadap Plasmodium, baik P. falciparum ataupun $P$. vivax termasuk yang resisten terhadap obat antimalaria konvensional, digunakan untuk mengatasi resistensi ini. ${ }^{2,3}$ Artemisinin merupakan senyawa endoperoksida siklik (sesquisterpene endoperoxide) yang akan mengoksidasi heme membentuk radikal bebas yang akan merusak membran plasma parasit dan mengganggu enzim parasit, sehingga menimbulkan kematian parasit tersebut dan mencegah polimerisasi heme lebih lanjut menjadi hemozoin yang tidak toksik. ${ }^{4}$ Radikal bebas yang terbentuk juga terlibat dalam kelainan patologik jaringan inang, misalnya kerusakan pada permukaan endotel pembuluh darah selama menderita malaria seperti pada malaria serebral ${ }^{5}$ dan terjadinya sekuestrasi eritrosit yang terinfeksi oleh stadium aseksual lanjut dalam kapiler dan venula jaringan pada berbagai organ yang menyebabkan kerusakan organ tersebut. ${ }^{6}$ Selain itu, stres oksidatif serta defisiensi antioksidan yang diakibatkan pemakaian artemisinin dapat mengakibatkan neuropati toksik berupa neurodegenerasi batang otak.

Suplementasi asam L askorbat yang dikenal sebagai vitamin $\mathrm{C}$ merupakan antioksidan yang larut dalam air dapat diupayakan untuk mengatasi dampak radikal bebas yang dihasilkan oleh artemisinin terhadap sel inang, karena asam L askorbat yang merupakan molekul hidrofilik diharapkan tidak dapat masuk ke dalam sel eritrosit yang terparasitisasi. Hal ini disebabkan karena pada membran eritrosit yang terparasitisasi terjadi suatu perubahan yang disebut jalur permeasi baru (new permeation pathway) mengakibatkan molekul yang dapat menembus membran eritrosit terparasitisasi tersebut hanyalah molekul kecil yang hidrofobik saja. ${ }^{8}$ Pada penyakit malaria falciparum yang menyerang anak-anak Nigeria didapatkan penurunan kadar asam L askorbat ini serta tingginya kadar lipid peroksida dalam plasma yang bertanggungjawab terhadap kerusakan jaringan pada penderita malaria. ${ }^{9}$ Pemberian asam L askorbat in vitro dapat mengurangi apoptosis sel endotel yang disebabkan malaria. ${ }^{10}$ Keterkaitan konsentrasi asam L askorbat dengan daya perlindungannya terhadap sel inang perlu dipelajari lebih lanjut sehubungan dengan kadar antioksidan dan prooksidan yang disebabkannya.
Penelitian ini bertujuan untuk mempelajari apakah asam $\mathrm{L}$ askorbat dalam kultur $P$. falciparum yang diinkubasi dengan artemisinin dapat meningkatkan viabilitas human umbilical vein endothelial cell (HUVEC) dan kadar glutation sulfil hidril (GSH), serta dapat menurunkan kadar malondialdehyde (MDA) secara in vitro.

\section{Metode}

Plasmodium falciparum beku strain 3D7 (diperoleh dari Lembaga Eijkman Jakarta), medium RPMI yang berisi eritrosit manusia dan serum manusia yang sudah diinaktivasi sebagai medium kultur Plasmodium, artemisinin proanalitik (Sigma-Aldrich), asam L askorbat proanalitik (3-Oxo-Lgulofuranolactone $=\mathrm{C} 6 \mathrm{H} 8 \mathrm{O} 6)$ diperoleh dari Phytotechnology Laboratories, Shawnee Mission, KS, USA, asam 2-tiobarbiturat (TBA) 0,67\%, larutan trichlor acetic acid (TCA) $20 \%$ dan 5\%, malondialdehyde (MDA) standar $(1,1,3,3$ tetraethoxypropane), reagen DTNB (5,5'-Dithiobis(2-ntrobenzoic acid) ) 39,6 mg dalam $10 \mathrm{~mL}$ dapar fosfat $0,1 \mathrm{M} \mathrm{pH} \mathrm{7,} \mathrm{larutan} \mathrm{standar}$ glutation (GSH) $2 \mathrm{mg} / \mathrm{mL}$ dalam dapar fosfat $\mathrm{pH} 8,0$, endothelial growth medium (EGM), EDTA, tripsin, gelatin 0,5\%, phosphate buffered saline (PBS), trypan blue, HUVEC yang diperoleh dari Cambrex.

Plasmodium falciparum beku dicairkan kemudian dikultivasi dalam medium kultur yang mengandung eritrosit dengan hematokrit $5 \%$ dan serum manusia $10 \%$ serta ditaruh dalam candle jar yang kemudian diinkubasi dalam inkubator suhu $37^{\circ} \mathrm{C}$. Medium kultur tiap hari diganti sampai mencapai stadium parasit yang sinkron dengan parasitemia $1-2 \%$. Pelet eritrosit dengan volume yang sama dimasukkan ke dalam masing-masing sumur pada lempeng mikro 4x6 yang berisi medium kultur dengan artemisnin $\mathrm{IC}_{50}$ (artemisinin dengan konsentrasi yang dapat menghambat $50 \%$ Plasmodium) dan asam askorbat berbagai konsentrasi, yaitu $0 \mu \mathrm{M}, 4 \mu \mathrm{M}, 20 \mu \mathrm{M}, 100 \mu \mathrm{M}, 500$ $\mu \mathrm{M}, 2.500 \mu \mathrm{M}$ sedemikian rupa sehingga volume masing-masing sumur adalah $1 \mathrm{~mL}$. Lempeng mikro kemudian diinkubasi dalam candle jar di dalam inkubator suhu $37^{\circ} \mathrm{C}$ selama 24 jam, kemudian dilakukan pengukuran kadar MDA pada supernatan kultur dengan metode thiobarbituric acid reactive substance (TBARS) melalui spektrofotometri panjang gelombang $532 \mathrm{~nm} .{ }^{11}$ Pengukuran kadar GSH pada supernatan kultur dilakukan dengan metode Ellman melalui spektrofotometri dengan panjang gelombang $412 \mathrm{~nm} .{ }^{12}$ Tahap berikutnya dilakukan kultur P. falciparum lagi seperti di atas dan sambil kultur Plasmodium, dilakukan thawing HUVEC yang kemudian dikultur menggunakan EGM dalam cawan petri. Setelah kultur mengalami 
konfluensi kira-kira 80\%, dilakukan subkultur dalam cawan mikro 4x6 dan setelah kultur mengalami konfluensi kira-kira 80\%, dilakukan kokultur dengan $P$. falciparum dengan jumlah parasit yang sama sedemikian rupa sehingga dalam kokultur tersebut berisi artemisinin IC50, asam L askorbat berbagai konsentrasi dalam medium kultur Plasmodium. Lempeng mikro kemudian diinkubasi di dalam inkubator $\mathrm{CO}_{2}$ suhu $37^{\circ} \mathrm{C}$ dengan kadar $\mathrm{CO}, 5 \%$ selama 24 jam. Setelah 24 jam, HUVEC dilepaskan dari dasar lempeng mikro dengan tripsin-EDTA, tripsin dinetralisasi dengan EGM, kemudian sebagian bahan tersebut dicampur dengan trypan blue dengan perbandingan 1:1 dan dilihat dengan mikroskop dalam kamar hitung improved Neubauer. Dihitung persentase HUVEC yang masih viable dibandingkan dengan seluruh HUVEC yang tampak. Hasil penelitian dianalisis dengan analysis of variance (ANOVA)dan uji Duncan.

\section{Hasil}

Kadar GSH yang diukur dalam supernatan kultur $P$. falciparum yang mencerminkan status antioksidan dalam kultur tersebut setelah diinkubasi dengan artemisinin $\mathrm{IC}_{50}$ dan berbagai konsentrasi asam L askorbat dapat dilihat pada Tabel 1 .
Setelah uji ANOVA yang bermakna dan kemudian dilanjutkan dengan uji Duncan, disimpulkan bahwa kadar GSH dalam $\mathrm{C}_{500}$ vs $\mathrm{C}_{2500}$, berbeda nyata. Kadar GSH dalam $\mathrm{C}_{20}$ vs $\mathrm{C}_{100}, \mathrm{KA}$, $\mathrm{K}$, dan $\mathrm{C}_{2500}$, juga berbeda nyata. Antara kadar GSH pada perlakuan lainnya satu sama lain tidak terdapat perbedaan yang bermakna. Konsentrasi asam L askorbat sebesar $20 \mu \mathrm{M}$ merupakan konsentrasi yang optimal kalau ditinjau pada kadar GSH-nya.

Kadar MDA yang diukur dalam supernatan kultur $P$. falciparum mencerminkan status oksidan dalam kultur tersebut setelah diinkubasi dengan artemisinin $\mathrm{IC}_{50}$ dan berbagai konsentrasi asam L askorbat dapat dilihat pada Tabel 2.

Berdasarkan uji ANOVA yang bermakna dan kemudian dilanjutkan dengan uji Duncan, diperoleh hasil kadar MDA dalam $\mathrm{C}_{2500} \mathrm{vs} \mathrm{C}_{500}, \mathrm{C}_{4}$, $\mathrm{KA}, \mathrm{C}_{20}, \mathrm{~K}$, dan $\mathrm{C}_{100}$, berbeda nyata. Kadar MDA dalam $\mathrm{C}_{500}$ vs $\mathrm{C}_{100}$, juga berbeda nyata. Antara kadar MDA pada perlakuan lainnya satu sama lain tidak terdapat perbedaan yang bermakna. Jadi, tampak pada Tabel 2 bahwa konsentrasi asam L askorbat $2.500 \mu \mathrm{M}$ merupakan konsentrasi yang malah meningkatkan kadar MDA.

Gambar memperlihatkan keadaan kultur HUVEC tingkat konfluensi 80-90\% dalam sumur mikro yang dilihat dengan mikroskop inversi dan sudah siap untuk diuji dalam kokultur dengan $P$.

Tabel 1 Kadar GSH $(\mu \mathrm{g} / \mathrm{mL})$ dalam Kultur P. falciparum yang Diinkubasi dengan Artemisinin IC $_{50}$ dan Asam L Askorbat Berbagai Konsentrasi

\begin{tabular}{llllllll}
\hline & $\mathbf{K}$ & $\mathbf{K A}$ & $\mathbf{C}_{4}$ & $\mathbf{C}_{20}$ & $\mathbf{C}_{100}$ & $\mathbf{C}_{500}$ & $\mathbf{C}_{2500}$ \\
\hline & 2,564 & 2,961 & 2,762 & 3,292 & 2,828 & 2,762 & 2,828 \\
& 2,696 & 2,828 & 2,895 & 3,424 & 2,895 & 3,358 & 2,630 \\
& 2,828 & 2,762 & 3,159 & 3,027 & 2,895 & 2,895 & 2,498 \\
\multirow{2}{*}{ Rata-rata } & $2,696^{\mathrm{ab}}$ & $2,850^{\mathrm{ab}}$ & $2,939^{\mathrm{abc}}$ & $3,248^{\mathrm{c}}$ & $2,873^{\mathrm{ab}}$ & $3,005^{\mathrm{bc}}$ & $2,652^{\mathrm{a}}$ \\
& $\pm 0,132$ & $\pm 0,101$ & $\pm 0,202$ & $\pm 0,202$ & $\pm 0,04$ & $\pm 0,312$ & $\pm 0,166$ \\
\hline
\end{tabular}

Keterangan: Huruf superscript yang sama menyatakan tidak berbeda secara bermakna pada $\mathrm{p}<0,05$

$\mathrm{K}=$ kultur $P$. falciparum tanpa artemisinin dan tanpa asam L askorbat

$\mathrm{KA}=\mathrm{K}$ yang diinkubasi dengan artemisinin $\mathrm{IC}_{50}$

$\mathrm{C}_{4}, \mathrm{C}_{20}, \mathrm{C}_{100}, \mathrm{C}_{500}, \mathrm{C}_{2.500}=\mathrm{KA}$ yang masing-masing diberi asam $\mathrm{L}$ askorbat konsentrasi $4 \mu \mathrm{M}, 20 \mu \mathrm{M}, 100 \mu \mathrm{M}$, $500 \mu \mathrm{M}$, dan $2.500 \mu \mathrm{M}$

Tabel 2 Kadar MDA (nmol/ mL) dalam Kultur P. falciparum yang Diinkubasi dengan Artemisinin $\mathrm{IC}_{50}$ dan Asam L Askorbat Berbagai Konsentrasi

\begin{tabular}{llllllll}
\hline & $\mathbf{K}$ & $\mathbf{K A}$ & $\mathbf{C}_{\mathbf{4}}$ & $\mathbf{C}_{\mathbf{2 0}}$ & $\mathbf{C}_{\mathbf{1 0 0}}$ & $\mathbf{C}_{\mathbf{5 0 0}}$ & $\mathbf{C}_{\mathbf{2 5 0 0}}$ \\
\hline & 0,336 & 0,276 & 0,288 & 0,312 & 0,264 & 0,384 & 0,587 \\
& 0,241 & 0,276 & 0,348 & 0,109 & 0,205 & 0,288 & 0,694 \\
\multirow{2}{*}{ Rata-rata } & 0,086 & 0,276 & 0,276 & 0,288 & 0,121 & 0,443 & 0,563 \\
& $0,221^{\mathrm{ab}}$ & $0,276^{\mathrm{ab}}$ & $0,304^{\mathrm{ab}}$ & $0,236^{\mathrm{ab}}$ & $0,197^{\mathrm{a}}$ & $0,372^{\mathrm{b}}$ & $0,615^{\mathrm{c}}$ \\
& $\pm 0,126$ & $\pm 0,000$ & $\pm 0,04$ & $\pm 0,111$ & $\pm 0,072$ & $\pm 0,078$ & 0,070 \\
\hline
\end{tabular}

Keterangan: Huruf superscript yang sama menyatakan tidak berbeda secara bermakna pada $\mathrm{p}<0,05$

$\mathrm{K} \quad=$ kultur $P$. falciparum tanpa artemisinin dan tanpa asam $\mathrm{L}$ askorbat

$\mathrm{KA}=\mathrm{K}$ yang diinkubasi dengan artemisinin $\mathrm{IC}_{50}$

$\mathrm{C}_{4}, \mathrm{C}_{20}, \mathrm{C}_{100}, \mathrm{C}_{500}, \mathrm{C}_{2.500}=\mathrm{KA}$ yang masing-masing diberi asam L askorbat konsentrasi $4 \mu \mathrm{M}, 20 \mu \mathrm{M}, 100 \mu \mathrm{M}$, $500 \mu \mathrm{M}$, dan $2.500 \mu \mathrm{M}$ 


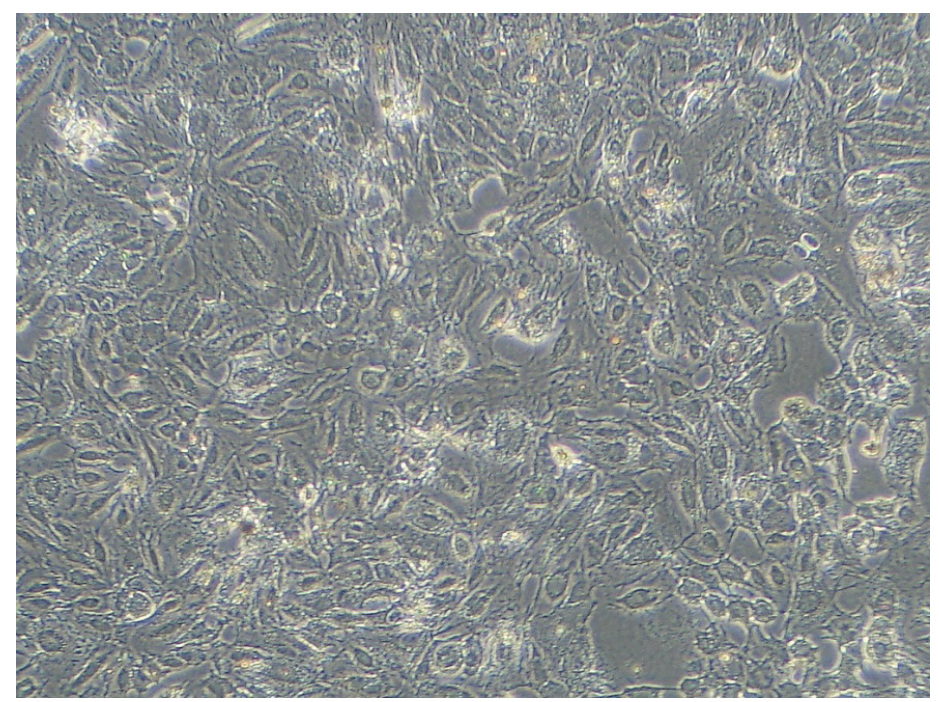

\section{Gambar Foto HUVEC Tanpa Pewarnaan dengan Perbesaran 200 Kali, dalam Lempeng Mikro Menggunakan Mikroskop Inversi, sebelum Diberi Perlakuan}

falciparum yang diinkubasi dengan artemisinin $\mathrm{IC}_{50}$ dan berbagai konsentrasi asam L askorbat.

Persentasi HUVEC yang hidup dalam kultur $P$. falciparum yang diinkubasi dengan artemisinin $\mathrm{IC}_{50}$ dan asam $\mathrm{L}$ askorbat berbagai konsentrasi mencerminkan kemampuan asam L askorbat dalam mencegah kerusakan sel sebagai akibat radikal bebas pada pemakaian artemisinin dapat dilihat pada Tabel 3.

Berdasarkan uji ANOVA yang bermakna dan kemudian dilanjutkan uji Scheffe dapat disimpulkan bahwa viabilitas HUVEC pada KA sama dengan pada $\mathrm{C}_{500}$ dan lebih kecil daripada viabilitas HUVEC pada K. Viabilitas HUVEC pada kultur yang mengandung artemisinin meningkat pada $\mathrm{C}_{20}$ dan $\mathrm{C}_{100}$, sedangkan viabilitas $\mathrm{HUVEC}$ pada $\mathrm{C}_{20}^{20}$ sama dengan $\mathrm{C}_{100}$. Viabilitasnya menurun kembali pada $\mathrm{C}_{500}$. Jadi pada $\mathrm{C}_{500}$, manfaat asam $\mathrm{L}$ askorbat sebagai peredam dampak negatif terhadap sel inang (HUVEC) tidak ada. Ditinjau dari viabilitas
HUVEC, konsentrasi optimal asam L askorbat yang dibutuhkan dalam kultur $P$. falciparum yang diberi artemisinin $\mathrm{IC}_{50}$ adalah $20 \mu \mathrm{M}$ dan $100 \mu \mathrm{M}$.

\section{Pembahasan}

Viabilitas HUVEC menurun dalam kultur yang diinkubasi dengan artemisinin dan asam L askorbat konsentrasi tinggi. Hal ini terjadi karena pada kultur yang diinkubasi dengan artemisinin dan konsentrasi asam $\mathrm{L}$ askorbat tinggi tersebut didapatkan parasitemia yang tinggi pula, ${ }^{13}$ sehingga terjadi hemolisis eritrosit yang terparasitisasi dalam jumlah besar yang mengakibatkan kadar feri heme dalam kultur juga meningkat. Asam L askorbat konsentrasi tinggi dalam cairan kultur bereaksi dengan feri heme yang juga dalam konsentrasi tinggi dan menghasilkan prooksidan ${ }^{14}$ dalam jumlah yang meningkat, sehingga kadar antioksidan

Tabel 3 Persentase HUVEC yang Hidup dalam Kokultur $P$. falciparum-HUVEC yang Diinkubasi Artemisinin $\mathrm{IC}_{50}$ dan Asam L Askorbat Berbagai Konsentrasi

\begin{tabular}{ccccccc}
\hline & $\mathbf{K}$ & $\mathbf{K A}$ & $\mathbf{C}_{4}$ & $\mathbf{C}_{20}$ & $\mathbf{C}_{100}$ & $\mathbf{C}_{500}$ \\
\hline \multirow{6}{*}{ Rata-rata } & 68 & 42 & 37,5 & 62 & 68 & 45 \\
& 52 & 45 & 54 & 60 & 57 & 35 \\
& $60^{\mathrm{bc}}$ & $43,5^{\mathrm{a}}$ & $45,75^{\mathrm{ab}}$ & $61^{\mathrm{bc}}$ & $62,5^{\mathrm{c}}$ & $40^{\mathrm{a}}$ \\
& $\pm 11,3$ & $\pm 2,12$ & $\pm 11,67$ & $\pm 1,41$ & $\pm 7,78$ & $\pm 7,07$ \\
\hline
\end{tabular}

Keterangan: Huruf superscript yang sama menyatakan tidak berbeda bermakna $(\mathrm{p}<0,1)$

$\mathrm{K}=$ kultur $P$. falciparum tanpa artemisinin dan tanpa asam L askorbat

$\mathrm{KA}=\mathrm{K}$ yang diinkubasi dengan artemisinin $\mathrm{IC}_{50}$

$\mathrm{C}_{4}, \mathrm{C}_{20}, \mathrm{C}_{100}, \mathrm{C}_{500}=\mathrm{KA}$ yang masing-masing diberi asam L askorbat konsentrasi $4 \mu \mathrm{M}, 20 \mu \mathrm{M}, 100 \mu \mathrm{M}$, dan $500 \mu \mathrm{M}$ 
termasuk kadar GSH akan menurun dan viabilitas HUVEC akan menurun serta kadar MDA yang mencerminkan derajat peroksidasi lipid akan meningkat. Dilaporkan juga bahwa keberadaan asam $\mathrm{L}$ askorbat konsentrasi tinggi baik secara in vitro maupun in vivo melalui pemberian secara intravena, dapat menghasilkan prooksidan yang mempunyai efek sitotoksik pada beberapa sel tumor sehubungan dengan produksi hidrogen peroksida. ${ }^{15}$

Konsentrasi optimal asam L askorbat untuk memperoleh persentase viabilitas HUVEC yang maksimal adalah $20 \mu \mathrm{M}$ dan $100 \mu \mathrm{M}$, karena pada konsentrasi tersebut tidak nyata tampak pengaruh buruk artemisinin pada HUVEC dalam kultur. Hal ini digambarkan dengan tidak adanya perbedaan viabilitas HUVEC kultur yang mengandung kedua konsentrasi asam L askorbat tersebut dengan kultur kontrol (K) yang tanpa artemisinin dan tanpa asam L askorbat. Hasil ini selaras dengan yang dilaporkan oleh Smith dkk. ${ }^{16}$ yang menyatakan bahwa asam L askorbat sebagai antioksidan pada konsentrasi $100 \mu \mathrm{M}$, selain glutation, dapat secara komplit mencegah neurotoksisitas artemisinin dan derivatnya pada studi hewan in vivo serta sel-sel neuron in vitro.

Viabilitas HUVEC maksimal didapatkan pada kultur yang diberi artemisinin dan mengandung asam L askorbat konsentrasi optimal, yaitu 20 $\mu \mathrm{M}$ dan $100 \mu \mathrm{M}$. Konsentrasi tersebut selaras dengan konsentrasi asam L askorbat dalam kultur $P$. falciparum yang diberi artemisinin dan mengandung konsentrasi GSH maksimal, yaitu konsentrasi asam L askorbat $20 \mu \mathrm{M}$. Konsentrasi $20 \mu \mathrm{M}$ juga merupakan konsentrasi yang optimal dalam meningkatkan daya antimalaria artemisinin dan menurunkan derajat parasitemia dalam kultur yang diinkubasi dengan artemisinin, ${ }^{13}$ sehingga dengan menurunnya derajat parasitemia, kadar prooksidan menurun dan hal ini diikuti oleh peningkatan viabilitas HUVEC. Konsentrasi MDA dalam kultur yang diberi artemisinin dengan asam L askorbat menunjukkan hasil yang tidak selaras dengan persentasi viabilitas HUVEC. Hal ini mungkin disebabkan perubahan ditinjau dari segi elektron yang tidak bersamaan dengan perubahan keadaan sel dalam arti dampak terhadap sel masih ada, akan tetapi kondisi elektron yang tadinya mengakibatkan perubahan sel tersebut sudah berubah lagi. Dengan perkataan lain, dapat disimpulkan bahwa perubahan kondisi elektron mendahului perubahan dalam sel dan kondisi elektron ini sangat mudah untuk berubah lagi. Hal ini perlu dipelajari lebih lanjut.

Hal di atas dapat menjadi dasar pemberian suplemen asam L askorbat pada terapi malaria falciparum menggunakan artemisinin untuk mencegah dampak negatif artemisinin tersebut terhadap sel inang. Intake asam L askorbat per oral sebanyak $100 \mathrm{mg} /$ hari pada populasi umumnya, akan menghasilkan konsentrasi asam L askorbat plasma sebesar $50 \mu \mathrm{M},{ }^{17}$ sehingga pada populasi umumnya, untuk memperoleh konsentrasi asam L askorbat plasma sebesar $100 \mu \mathrm{M}$ supaya efek neurotoksik artemisinin dapat dicegah, diperlukan intake asam L askorbat yang lebih dari $100 \mathrm{mg} /$ hari. Berapa tepatnya besar intake tersebut perlu diteliti lebih lanjut, terlebih lagi pada penderita malaria falciparum kemungkinan intake asam L askorbat yang dibutuhkan untuk dapat menghasilkan konsentrasi asam L askorbat plasma tersebut mungkin berbeda dengan populasi umumnya.

Malaria berat sendiri yang terjadi pada anak menyebabkan lebih rendahnya kadar asam L askorbat dan vitamin A secara signifikan dibandingkan dengan malaria ringan atau sedang. Hal ini membuktikan bahwa mikronutrien tersebut dipakai dalam menghadapi peningkatan parasitemia. ${ }^{18,19}$ Rendahnya kadar antioksidan tersebut pada anak yang terinfeksi ini kemungkinan disebabkan sebagian oleh peningkatan utilisasi atau peningkatan destruksi pada malaria. ${ }^{20}$ Pemberian antioksidan seperti asam L askorbat sangat direkomendasikan pada malaria karena didapatkan penurunan kadar zat tersebut, apalagi kalau malaria tersebut mendapat terapi artemisnin yang juga mempunyai andil dalam hal peningkatan kadar radikal bebas yang berarti akan mempunyai andil pula dalam menurunkan kadar antioksidan termasuk asam L askorbat. Pendapat penulis ini selaras dengan hasil studi Nmorsi dkk. ${ }^{19}$ yang menyatakan bahwa akhir-akhir ini penanganan malaria dilakukan tanpa atau sedikit sekali dengan pemberian antioksidan. Berdasarkan hasil studi yang mendapatkan keadaan rendahnya kadar antioksidan pada anak penderita malaria dibandingkan dengan anak yang sehat, pemberian suplementasi mikronutrien seperti vitamin $\mathrm{A}$, vitamin $\mathrm{C}$, dan vitamin $\mathrm{E}$ perlu diikutsertakan pada pengobatan infeksi $P$. falciparum. ${ }^{19}$

Dari data hasil penelitian di atas dapat disimpulkan bahwa daya asam L askorbat sebagai antioksidan bersifat dose dependent yang berarti ditentukan oleh dosis yang pada akhirnya menentukan konsentrasi asam L askorbat tersebut dalam kultur. Sifat sebagai pisau bermata dua berlaku untuk asam L askorbat ini, yaitu pada konsentrasi tertentu, asam $\mathrm{L}$ askorbat ini bersifat sebagai antioksidan, sedangkan pada konsentrasi yang lebih besar, zat ini bersifat sebagai prooksidan.

\section{Ucapan Terima Kasih}

Dirjen Dikti Depdikbud yang telah mendanai sebagian penelitian ini melalui program Hibah Bersaing. 


\section{Daftar Pustaka}

1. Na-Bangchiang K, Congpuong K. Current malaria status and distribution of drug resistance in east and Southeast Asia with special focus to Thailand. Tohoku J Exp Med. 2007;211:99-113.

2. Ratcliff A, Siswantoro H, Kenangalem E, Maristela R, Wuwung RM, Laihad F, dkk. Two fixed-dose artemisinin combinations for drug-resistant falciparum and vivax malaria in Papua, Indonesia: an open-label randomised comparison. Lancet. 2007;369(9563):75765.

3. Phan Giao T, de Vries Peter J, Tran Binh Q, Le Hung Q, Nguyen Nam V, Nguyen Thang $\mathrm{V}, \mathrm{dkk}$. Artemisinin or chloroquine for blood stage Plasmodium vivax malaria in Vietnam. Tropical Med Intern Hlth. 2002;7(10):85864.

4. Tonmunphean S, Parasuk V, Kokpol S. QSAR study of antimalarial activities and artemisinin-heme binding properties obtained from docking calculations. Quan Struct Act Relat. 2000;19:475.

5. Mohanty S, Patel DK, Pati SS, Mishra SK. Adjuvant therapy in cerebral malaria. Indian J Med Res. 2006;124:245-60.

6. Becker K, Tilley L, Vennerstrom JL, Roberts D, Rogerson S, Ginsburg H. Oxidative stress in malaria parasite-infected erythrocytes: host-parasite interactions. Int $\mathrm{J}$ Parasitol. 2004;34(2):163-89.

7. Schmuck G, Roehrdanz E, Hayes RK, Kahl R. Neurotoxic mode of action of artemisinin. Antimicrob Agents Chemother. 2002;46(3):821-7.

8. Egwunyenga AO, Isamah G, Nmorsi OPG. Lipid peroxidation and ascorbic acid levels in Nigeria children with acute falciparum malaria. African J Biotechnol. 2004;3(10):560-3.

9. Hemmer CJ, Lehr HA, Westphal K, Unverricht M, Kratzius M, Reisinger EC. Plasmodium falciparum malaria: reduction of endothelial cell apoptosis in vitro. Infect Immunity. 2005;76(3):1764-70.

10. Kirk K. Membrane transport in malariainfected erythrocyte. Physiological Rev.
2001;81(2):495-537.

11. Wills ED. Evaluation of lipid peroxidation in lipids and biological membranes. Dalam: Snell K, Mullock B, penyunting. Biochemical toxicology, a practical approach. Oxford: IRL Press; 1987. hlm. 127-52.

12. Ellman GL. Tissue sulphidryl groups. Arch Biochem Biophysics. 1959;82:70-7.

13. Tjahjani S, Achmad TH, Syafruddin D, Agoes R, Sujatno M. Asam Laskorbat meningkatkan aktivitas antimalaria artemisinin bergantung konsentrasi. MKB. 2008;40(4):176-80.

14. Mauricio AQ, Lopes GK, Gomes CS, Oliveira RG, Alonso A, Hermes-Lima M. Pyridoxal isonicotinoyl hydrazone inhibits ironinduced ascorbate oxidation and ascorbyl radical formation. Biochem Biophys Acta. 2003;1620(1-3):15-24.

15. Chen Q, Espey MG, Sun AY, Pooput C, Kirk KL, Krishna MC, dkk. Pharmacologic doses of ascorbate act as a prooxidant and decrease growth of aggressive tumor xenografts in mice. Proceeding of the National Academy of Sciences of the United States of America. 2008;105(32):11105-9.

16. Smith SL, Maggs JL, Edwards G, Ward SA, Park BK, McLean WG. The role of iron in neurotoxicity: a study of novel antimalarial drugs. Neurotoxicology. 1998;19(4-5):5579.

17. Brubacher D, Moser U, Jordan P. Vitamin $\mathrm{C}$ concentrations in plasma as a function of intake: a meta-analysis. Int J Vitam Nutr Res. 2000;70(5):226-37.

18. Akpotuzor JO, Udoh AE, Etukudo $\mathrm{MH}$. Total antioxidant status, vitamin A, C, and carotene levels of children with $P$. falciparum infection in University of Calabar Teaching Hospital (UCTH), Calabar. Pakistan J Nut. 2007;6(5):485-9.

19. Nmorsi OPG, Ukwandu NCD, Egwunyenga AO. Antioxidant status of Nigerian children with Plasmodium falciparum malaria. African J Microbiol Research. 2007:161-4.

20. Prasannachandra, D'Souza V, D'Souza B. Comparative study on lipid peroxidation and antioxidant vitamins $\mathrm{E}$ and $\mathrm{C}$ in falciparum and vivax malaria. Indian $\mathrm{J}$ Clin Biochem. 2006;21(2):103-6. 